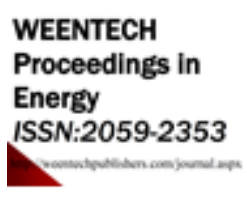

Available online at www.weentechpublishers.com

\title{
Assessing low energy school buildings using the new Building Bulletin 101
}

\author{
Yingchun $\mathrm{Ji}^{* \mathrm{a}}$. Jiangtao $\mathrm{Du}^{\mathrm{b}}$ \\ ${ }^{a}$ School of Science, Engineering and Environment, University of Salford, The Crescent, Salford, M5 4WT, UK \\ ${ }^{b}$ School of Architecture, University of Liverpool, Liverpool, L69 7ZN, UK \\ *Corresponding author's mail: y.ji@salford.ac.uk
}

\begin{abstract}
This paper reports an assessment of a school building design using the newly published Building Bulletin 1012018 . The requirements on thermal comfort and $\mathrm{CO}_{2}$ based indoor air quality from this new guidance document are very different from its earlier version published in 2006. Existing research reported that the new requirements are much tougher to meet compared with the previous version. The aim of this research is to examine whether design alternatives on an existing school building with 10 learning and teaching spaces can help in passing the new requirements using dynamic thermal simulation tool - IESVE.

It is found that promoting ventilation, shading and night purging can all help mitigating overheating in the ten learning and teaching spaces evaluated. With the 'as built' condition, these learning and teaching spaces failed all three overheating criteria from the new BB101. Promoting ventilation can help some of the spaces pass the overheating occurrence criterion but not the overheating severity criteria. With added shading to block excessive solar gains, half of the evaluated spaces were able to pass the thermal comfort requirement. Boosting the night purging also helps to some extent in bridging the gap against the target requirements on overheating severity, however, there are still spaces which will not pass the comfort requirement. This may indicate that natural ventilation itself may not be able to provide thermal comfort for the given design. $\mathrm{CO}_{2}$ based indoor air quality requirements are less of an issue as higher $\mathrm{CO}_{2}$ concentrations always happen when the outdoor air temperature is low, boosting ventilation using automatic or manual control can easily resolve this. The research also highlights that one of the overheating criteria is much more difficult to meet, the appropriateness of this criterion is therefore in question. As the new BB101 was only launched very recently, it will be subject to further tests and evaluations in order to examine whether it fits for purpose.
\end{abstract}

Keywords: Building Bulletin 101; Overheating; Adaptive Thermal Comfort; Design Summer Year; Dynamic Thermal Simulation

Copyright (C) 2019 Published by WEENTECH Publishers. This is an open access article under the CC BY License (http://creativecommons.org/licenses/BY/4.0/). All Peer-review process under responsibility of the scientific committee of the $4^{\text {th }}$ International Conference on Energy, Environment and Economics, ICEEE2019

https://doi.org/10.32438/WPE.7019

Manuscript History

Receipt of completed manuscript: 01 May 2019

Receipt of Revised Manuscript: 22 May 2019

Date of Acceptance: 23 May 2019

Online available from: 06 September 2019 


\section{Abbreviations}

BB101 Building Bulletin 101

DSY Design Summer Year

TRY Test Reference Year

CIBSE Chartered Institution of Building Service

Engineers

WCDH Weighted Cooling Degree Hours

IESVE Integrated Environmental Solutions Virtual

Environment

\section{Introduction}

It has been evident that school children's cognitive performances can be significantly impacted by their learning environment [1-3]. For new school building designs as well as retrofitting existing schools, achieving a good indoor environment for pupil's various learning activities should be put at the centre of such projects. In the UK, Building Bulletin 101 (BB101) is a dedicated guidance document for the design of school buildings. Prior the new update in 2018 [4], BB101 (2006) primarily focused on ventilation of school buildings [5]. The new update BB101 (2018) provides guidelines not only on ventilation but also emphasizes thermal comfort and indoor air quality in schools. This latest update (which published on the UK government website), entitled 'Guidelines for ventilation, thermal comfort and IAQ in schools', provides a holistic approach for school building design and retrofit with added emphasis on energy consumptions and controllability. The key design requirements for thermal comfort and $\mathrm{CO}_{2}$ based indoor air quality from BB101 (2018) is summarized in Table 1.

Table 1 BB101 (2018) compliance calculation requirements on weather, occupancy, ventilation, $\mathrm{CO}_{2}$, and thermal comfort for teaching and learning spaces [4]

\begin{tabular}{ll}
\hline & BB101 (2018) Guidance requirements \\
\hline Weather data used for assessment & Using future projected Design Summer Year weather data $-\mathrm{pDSY}-1(2020)$ \\
Occupancy time for assessment & $9: 00$ to $16: 00 /$ Mon. to Fri. / $1^{\text {st }}$ of May to $30^{\text {th }}$ of September \\
Ventilation (1/s/p - litre per second & For Mechanical ventilation -8 to $9 \mathrm{l} / \mathrm{s} / \mathrm{p}$ \\
per person & For Natural ventilation $-5 \mathrm{l} / \mathrm{s} / \mathrm{p}$ \\
$\mathrm{CO}_{2}$ concentrations & Maximum $\leq 2000 \mathrm{ppm}$ for more than 20 minutes; Average $\leq 1000 \mathrm{ppm}$ \\
Thermal comfort criteria (two out & Hours of exceedance $\leq 40$ hours; Daily weighted exceedance $\leq 6 ;$ The temperature \\
of the three criteria need to be met) & difference (between maximum indoor operative temperature and comfort temperature \\
& upper limit temperature) $\leq 4 \mathrm{~K}$ \\
\hline
\end{tabular}

For building compliance calculations, standardized weather data are often used. In the UK there are two types of standardized weather data: Test Reference Year (TRY) and Design Summer Year (DSY) [6]. Based on historical recorded weather data over typically 20 to 30 years, a TRY represents an averaged weather condition which is often used for building energy consumption calculation. While for a DSY, it represents a near extreme weather condition and is used for building overheating assessment. Both TRYs and DSYs were made available for 14 cities in the UK: Belfast, Birmingham, Cardiff, Edinburgh, Glasgow, Leeds, London, Manchester, Newcastle, Norwich, Nottingham, Plymouth, Southampton, and Swindon. There are three weather stations in London - Heathrow, Gatwick \& London Weather Centre, so in total there are 16 weather datasets available across the country. In the recent release of weather data from CIBSE 2016, DSYs were no longer selected by the mid of the upper quartile of the base weather years [7], instead, a new metric 'weight cooling degree hours (WCDH)' was used [8,9]: 


$$
W C D H=\sum_{i=1}^{N}\left(T_{d b t}^{i}-T_{\text {comf }}^{i}\right)^{2} \mid T_{d b t}^{i}>T_{\text {comf }}^{i}
$$

where $T_{\text {comf }}^{i}$ represents the comfort temperature defined by adaptive thermal comfort [10], $i$ is the individual hours, $T_{d b t}^{i}$ is the dry-bulb temperature at hour $i$, which is assumed to be the same as the indoor operative temperature under the conceptual building assumption [6], and $N$ is the total hours from April to September inclusive (4392 hours).

The baseline weather data used for the recent release of DSYs and TRYs are from 1984 to 2013 [6]. Using London as an example, the probabilistic DSYs were chosen by calculating their return periods of the new metric WCDH. A longer return period represents a more severe of the summer warmth. For example, in Heathrow, pDSY-1 (Heathrow 1989) represents a moderately warm summer; pDSY-2 (Heathrow 2003) has a more intense single warm spell; and pDSY-3 (Heathrow 1976) has a long period of persistent warmth. Using these current pDSYs, future projected pDSYs were also included in the new release for 2020, 2050 and 2080. For the compliance calculation of school buildings, it is recommended that a future moderate warm summer pDSY-1 2020 will be used [4].

The overheating criteria used in BB101 2018 were derived from the adaptive thermal comfort approach, detailed discussions can be found from the relevant standards such as BS EN 15251 [10], CIBSE Guide A [11], and more specifically TM52 [12]. The adaptive thermal comfort approach emphasizes the influence of outdoor running mean temperature on the indoor comfort temperature. The comfort temperature is defined as:

$$
\begin{aligned}
& T_{\text {comf }}=0.33 \operatorname{Max}\left(10, T_{r m}\right)+18.8 \\
& T_{r m}=(1-\alpha) T_{e d-1}+\alpha T_{r m-1}
\end{aligned}
$$

with

$T_{\text {comf }}$ is the comfort temperature, $T_{r m}$ is the outdoor running mean temperature. The previous day's daily mean and running mean temperatures are $T_{e d-1}$ and $T_{r m-1}$. A constant $\alpha$ (between 0 and 1) is used to account the influences of daily mean temperature on the running mean temperature, $\alpha=0.8$ is recommended by BS EN 15251 [10]. For Category II normal expectations of thermal comfort, the comfort upper limiting temperature $\left(T_{\text {c.u.l.t }}\right)$ is defined as:

$$
T_{\text {c.u.l.t }}=T_{\text {comf }}+3
$$

As presented in BB101 2018 and TM52 [12], the Hours of Exceedance $\left(H_{e}\right)$ in table 1 are counted based on the temperature differences between the indoor operative temperature $T_{o p}$ and the comfort upper limiting temperature $T_{\text {c.u.l.t }}\left(\Delta T=T_{o p}-T_{\text {c.u.l.t }}\right)$. This requirement for $H_{e}$ is that 'the number of hours $\left(H_{e}\right)$ during which $\Delta T$ is greater than or equal to one degree $(K)$ during the period $1^{\text {st }}$ of May to $30^{\text {th }}$ of September for the defined hours inclusive shall not be more than 40 hours'. $\Delta T$ is rounded to the nearest degree (i.e. for $\Delta T$ between 0.5 and 1.5 the value used is $1^{\circ} \mathrm{C}$, for 1.5 to 2.5 the value used is $2^{\circ} \mathrm{C}$ and so on). The daily weighted exceedance $\left(W_{e}\right)$ is the 'daily accumulated number of hours over' for that day, counting the sum of all the rounded $\Delta T$. The temperature difference criterion assesses the difference between the maximum indoor operative temperature and the comfort upper limiting temperature on the day $\left(\Delta T_{\max }=T_{o p-\max }-T_{\text {c.u.l.t }}\right)$, the difference $\Delta T_{\max }$ should be less or equal $4^{\circ} \mathrm{C}$. The compliance calculation requires to pass at least two out of these three criteria for a particular design.

Recent studies indicate that the requirements for thermal comfort and $\mathrm{CO}_{2}$ concentrations from the new BB101 update are much tougher to meet. The case with multiple learning spaces which met the 
BB101 2006's requirements could easily fail to meet what required by BB101 2018 [13]. The aim of this work is to explore various design features which could assist ventilation effectiveness and help in mitigating the likelihood of overheating in school buildings. Considering the fact that this new guidance document has not been explored substantively since its recent launch, this research takes the opportunity to apply these new criteria in design and examine its impact on the future design of school buildings.

\section{The school building model}

An existing 4-storey preparatory school building is used in this research. It is a naturally ventilated school built in late 2008 in central London (Fig. 1). There are ten teaching and learning spaces (the plan view of Fig. 1). Due to the existing site conditions, all the windows of these learning and teaching spaces are east facing. There are no openable windows on the west side to avoid the noise from a busy road adjacent. Therefore, ventilation of these spaces is provided by opening windows on east façade, ventilation louvres and roof terminals with or without stacks.
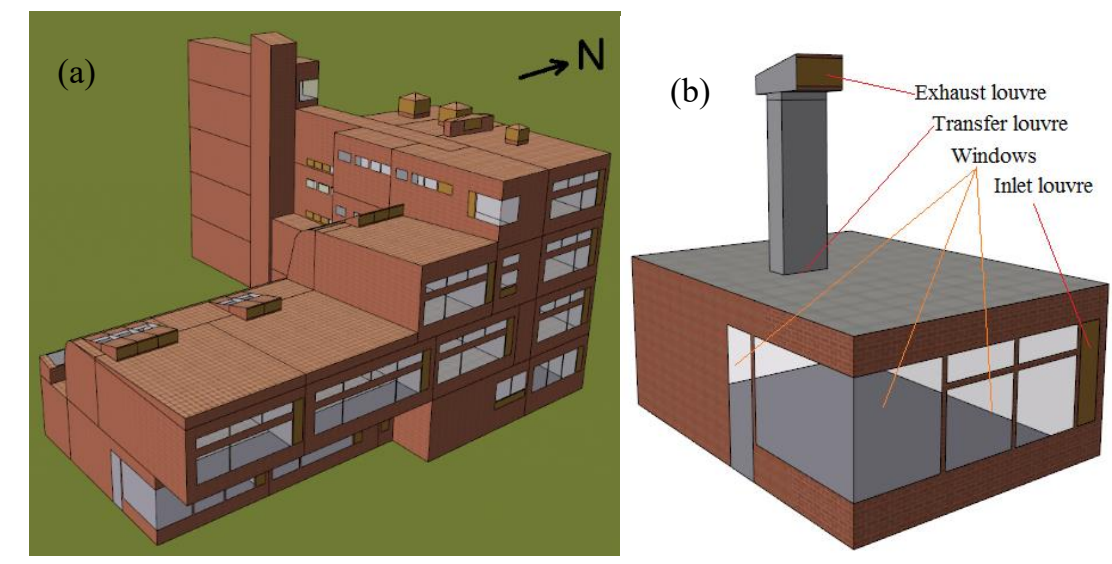

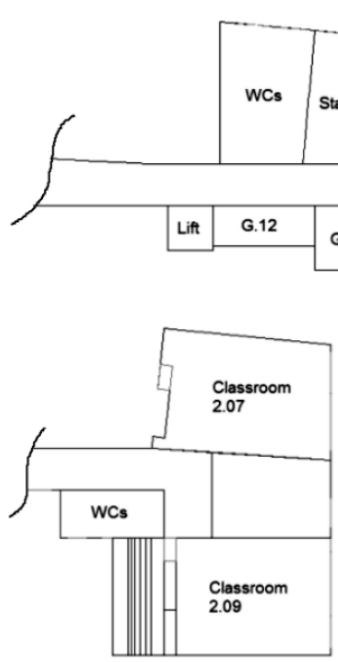

Second Floor

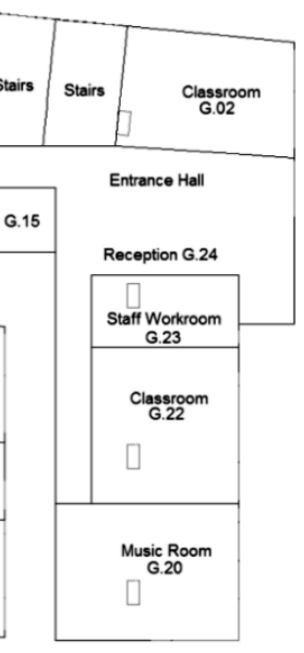

Ground Floor

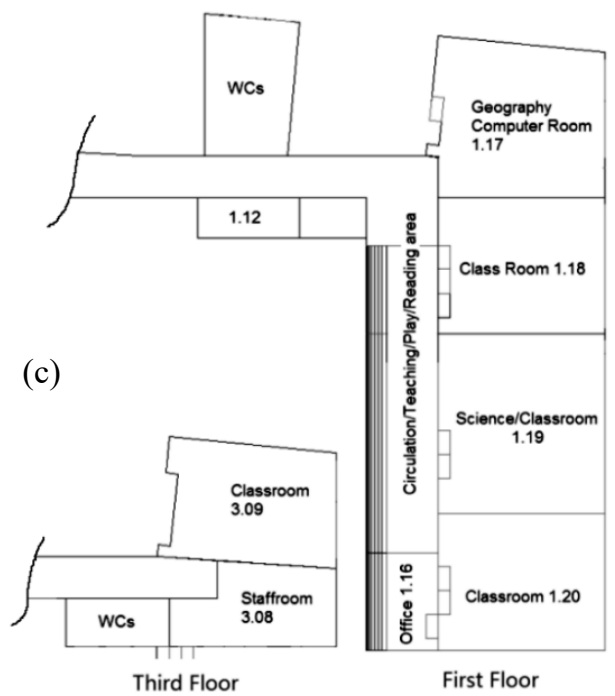

Fig. 1 (a) the school model; (b) one classroom showing ventilation routes and (c) the plan view of the school (the narrow side of the building was now shown in the plan view)

As shown in Fig. 1 plan view, ground floor has three teaching and learning spaces ( 2 class rooms G.02 \& G.22, and G.20 which is a music room); there are 3 classrooms and a computer room in the first 
floor $(\mathrm{F} 1.18, \mathrm{~F} 1.19, \mathrm{~F} 1.20 \& \mathrm{~F} 1.17)$; on the second floor there are two classrooms - F2.07 \& F2.09; classroom T3.09 is on the third floor. Each of these teaching and learning spaces has designated natural ventilation route, cross ventilation between these spaces is avoided through design. These 10 teaching and learning spaces have different layouts, stack heights, internal gains, roof terminals, ventilation routes and volumes. In this work, we use these spaces to carry out the compliance check against BB101 2018.

The school was built on an existing site. Its adjacent buildings are included as parts of the model to take into account their shading effects. Following the building design specifications, the thermal transmittances (U-values) of different facades are benefited from appropriate insulations which have led to low U-values compared with the current building regulations: Zinc roof $\left(0.14 \mathrm{~W} / \mathrm{m}^{2} \mathrm{~K}\right)$; Sarnafil roof $\left(0.12 \mathrm{~W} / \mathrm{m}^{2} \mathrm{~K}\right)$; External walls $\left(0.15 \mathrm{~W} / \mathrm{m}^{2} \mathrm{~K}\right)$; Ground floor $\left(0.27 \mathrm{~W} / \mathrm{m}^{2} \mathrm{~K}\right)$; External glazing $(1.09$ $\left.\mathrm{W} / \mathrm{m}^{2} \mathrm{~K}\right)$; Internal Walls $\left(0.29 \mathrm{~W} / \mathrm{m}^{2} \mathrm{~K}\right)$; Intermediate floors $\left(0.62 \mathrm{~W} / \mathrm{m}^{2} \mathrm{~K}\right)$.

\section{Methodologies}

The compliance calculation of the given model was done by IESVE. IESVE is a well-established dynamic thermal simulation tool which uses the hourly weather data to examine the dynamic responses of a building [14]. Table 2 provides the details of the ventilation louvres, windows and their free opening areas for each individual teaching and learning space of interest, as well as the details on the incidental heat gains of each room. An overhead projector (maximum output 250 watts) is included in each space and the lighting gain is assumed at $10 \mathrm{~W} / \mathrm{m}^{2}$ during occupancy. Room F1.17 is a computer suite with 23 laptops at 60 watts per laptop. These assumptions on heat gains were from the CIBSE Guide A [11]. For dynamic thermal modelling the maximum gain (worst case scenario) was used to do the compliance calculation. Apart from F1.17 which has a maximum gain at $85.7 \mathrm{~W} / \mathrm{m}^{2}$, other spaces are between $50 \mathrm{~W} / \mathrm{m}^{2}$ to $61 \mathrm{~W} / \mathrm{m}^{2}$.

A nodal network airflow model Marcro-flo was used for ventilation modelling. This model is an integrated part of the IESVE tool suite, which considers the prevailing driving forces of wind and buoyancy. The amount ventilation will be calculated in referencing the free areas of the ventilation louvres, vertical stacks with transfer grills, roof air extract terminals/louvres and openable windows. During occupancy, behaviour related controls on the opening of ventilation routes were used in referencing indoor and outdoor temperature, $\mathrm{CO}_{2}$ concentrations. Ramp functions were used to regulate the degree of openings, i.e. when indoor air temperature change from $20^{\circ} \mathrm{C}$ to $24{ }^{\circ} \mathrm{C}$ (from $800 \mathrm{ppm}$ to $2000 \mathrm{ppm}$ for $\mathrm{CO}_{2}$ concentration) the degree of opening for windows and louvres will vary from fully closed to fully open. Night cooling is considered by keeping the inlet louvres open at night.

The school building was first assessed under 'as built' condition against the adaptive overheating criteria from the new BB101. The mitigations of overheating were considered by:

- Case 1 - increasing ventilation free opening areas by $20 \%$ where appropriate (including all Louvres and Airstract. Originally fixed windows are now opened $20 \%$ during occupancy, the openable windows were kept unchanged as they are already full or nearly full open);

- Case 2 - adding external shutters for windows to avoid excessive solar gains (when incident radiation is higher than $300 \mathrm{~W} / \mathrm{m}^{2}$, the shutters will be closed, shutters are fully open when the incident radiation is less or equal $\left.300 \mathrm{~W} / \mathrm{m}^{2}\right)$;

- Case 3-promote night time ventilation (night ventilation or purging is very important for naturally ventilated buildings to combat summer warmth. Under as built condition, Louvres are already 
serving the night ventilation purpose, in this case we also consider leaving the windows open $20 \%$ at night time to boost night ventilation).

Table 2 Ventilation openings, internal heat gains, floor areas and occupancy details for individual teaching and learning spaces (as built specifications).

\begin{tabular}{|c|c|c|c|c|c|c|c|c|c|}
\hline \multirow[t]{2}{*}{ Room } & \multirow[t]{2}{*}{ Opening Types } & \multirow{2}{*}{$\begin{array}{c}\text { Free Area } \\
\left(\mathbf{m}^{2}\right)\end{array}$} & \multirow[t]{2}{*}{$\mathrm{C}_{\mathrm{d}}{ }^{1}$} & \multicolumn{3}{|c|}{ Internal gains } & \multirow{2}{*}{$\begin{array}{c}\text { Floor Area } \\
\left(\mathrm{m}^{2}\right)\end{array}$} & \multicolumn{2}{|c|}{ Total gain } \\
\hline & & & & Occupancy & Equipment & Lighting & & $(\mathrm{W})$ & $\left(\mathrm{W} / \mathrm{m}^{2}\right)$ \\
\hline \multirow[t]{4}{*}{ G.02 } & Louvre (inlet) & 0.112 & 0.4 & & & & & & \\
\hline & Transfer Louvre & 0.192 & 0.55 & 1 Adult + & $250 \mathrm{~W}$ & $10 \mathrm{~W} / \mathrm{m}^{2}$ & 35.6 & 2120.6 & 59.5 \\
\hline & Airstract $^{2}$ (shared $)$ & 0.368 & 0.61 & 19 Pupils & & & & & \\
\hline & Openable windows ${ }^{3}$ & 4.3 & 0.61 & & & & & & \\
\hline \multirow[t]{4}{*}{ G.20 } & Louvre (inlet) & 0.136 by 8 & 0.4 & & & & & & \\
\hline & Transfer Louvre & 0.201 & 0.55 & 1 Adult + & $250 \mathrm{~W}$ & $10 \mathrm{~W} / \mathrm{m}^{2}$ & 43.7 & 2425.9 & 55.5 \\
\hline & Louvre (exhaust) & 0.274 by 2 & 0.4 & 22 Pupils & & & & & \\
\hline & Openable windows 3 & - & 0.61 & & & & & & \\
\hline \multirow[t]{4}{*}{ G.22 } & Louvre (inlet) & 0.136 by 8 & 0.4 & & & & & & \\
\hline & Transfer Louvre & 0.201 & 0.55 & 1 Adult + & $250 \mathrm{~W}$ & $10 \mathrm{~W} / \mathrm{m}^{2}$ & 40.3 & 2166.0 & 53.8 \\
\hline & Louvre (exhaust) & 0.274 by 2 & 0.4 & 19 Pupils & & & & & \\
\hline & Openable windows ${ }^{3}$ & - & 0.61 & & & & & & \\
\hline \multirow[t]{4}{*}{ F1.17 } & Louvre (inlet) & 0.112 & 0.4 & & $250 W+23$ & & & & \\
\hline & Transfer Louvre & 0.201 & 0.55 & 1 Adult + & laptops & $10 \mathrm{~W} / \mathrm{m}^{2}$ & 45.5 & 3899.3 & 85.7 \\
\hline & Airstract ${ }^{* 1}$ (shared) & 0.368 & 0.4 & 23 Pupils & (60W each) & & & & \\
\hline & Openable windows ${ }^{3}$ & 3.08 & 0.61 & & & & & & \\
\hline \multirow[t]{4}{*}{ F1.18 } & Louvre (inlet) & 0.112 & 0.4 & & & & & & \\
\hline & Transfer Louvre & 0.201 & 0.55 & 1 Adult + & $250 \mathrm{~W}$ & $10 \mathrm{~W} / \mathrm{m}^{2}$ & 38.7 & 2227.6 & 57.5 \\
\hline & Louvre (exhaust) & 0.238 by 2 & 0.4 & 20 Pupils & & & & & \\
\hline & Openable windows ${ }^{3}$ & 3.89 & 0.61 & & & & & & \\
\hline \multirow[t]{4}{*}{$\mathrm{F} 1.19$} & Louvre (inlet) & 0.112 & 0.4 & & & & & & \\
\hline & Transfer Louvre & 0.201 & 0.55 & 1 Adult + & $250 \mathrm{~W}$ & $10 \mathrm{~W} / \mathrm{m}^{2}$ & 52.0 & 2883.8 & 55.5 \\
\hline & Louvre (exhaust) & 0.238 by 2 & 0.4 & 27 Pupils & & & & & \\
\hline & Openable windows 3 & 5.73 & 0.61 & & & & & & \\
\hline \multirow[t]{4}{*}{$\mathrm{F} 1.20$} & Louvre (inlet) & 0.112 & 0.4 & & & & & & \\
\hline & Transfer Louvre & 0.201 & 0.55 & 1 Adult + & $250 \mathrm{~W}$ & $10 \mathrm{~W} / \mathrm{m}^{2}$ & 39.2 & 2232.8 & 56.9 \\
\hline & Louvre (exhaust) & 0.238 by 2 & 0.4 & 20 Pupils & & & & & \\
\hline & Openable windows ${ }^{3}$ & 3.89 & 0.61 & & & & & & \\
\hline \multirow[t]{4}{*}{ S2.07 } & Louvre (inlet) & 0.112 & 0.4 & & & & & & \\
\hline & Transfer Louvre & 0.219 & 0.55 & 1 Adult + & $250 \mathrm{~W}$ & $10 \mathrm{~W} / \mathrm{m}^{2}$ & 34.6 & 2036.2 & 58.8 \\
\hline & Airstract ${ }^{* 1}$ (shared) & 0.368 & 0.4 & 18 Pupils & & & & & \\
\hline & Openable windows ${ }^{3}$ & 3.08 & 0.61 & & & & & & \\
\hline \multirow[t]{4}{*}{ S2.09 } & Louvre (inlet) & 0.112 & 0.4 & & & & & & \\
\hline & Transfer Louvre & 0.219 & 0.55 & 1 Adult + & $250 \mathrm{~W}$ & $10 \mathrm{~W} / \mathrm{m}^{2}$ & 33.2 & 2022.8 & 61.0 \\
\hline & Louvre (exhaust) & 0.256 by 2 & 0.4 & 18 Pupils & & & & & \\
\hline & Openable windows ${ }^{3}$ & 3.14 & 0.61 & & & & & & \\
\hline \multirow[t]{4}{*}{ T3.09 } & Louvre (inlet) & 0.112 & 0.4 & & & & & & \\
\hline & Transfer Louvre & 0.293 & 0.55 & 1 Adult + & $250 \mathrm{~W}$ & $10 \mathrm{~W} / \mathrm{m}^{2}$ & 34.1 & 2030.1 & 59.5 \\
\hline & Airstract (shared) & 0.384 & 0.61 & 18 Pupils & & & & & \\
\hline & Openable windows ${ }^{3}$ & 2.75 & 0.61 & & & & & & \\
\hline
\end{tabular}

${ }^{1}$ Discharge coefficients; ${ }^{2}$ One $1250 \mathrm{~mm} \times 575 \mathrm{~mm}$ Airstract was shared by Rooms G02, F117 \& S207; ${ }^{3}$ These openable windows are either 'tilt and turn' windows or 'bottom-hinged' windows, their free areas are the maximum openable areas.

\section{Results and discussions}

Results for compliance calculation on thermal comfort using IESVE were shown in Table 3. For 
as built condition, none of the room was able to pass the given criteria in BB101 2018. More specifically, except room F1.20, none of other rooms pass any of the three criteria. Earlier assessment for the school indicated that all the rooms could pass the BB101 2006 requirements [13]. This indicates that the new BB101 2018 indeed has much more stringent requirements on thermal comfort. The considered cases in this work aimed to help mitigating summer warmth. For Case 1, although increasing ventilation can help reduce the overheating occurrence and severity compared with the base case (as built), all these assessed rooms still failed to meet the given thermal comfort criteria (pass two out of the three criteria). With the help of appropriate shadings, five out of ten rooms were able to pass the latest thermal comfort requirements from the new BB101. It is obvious that the 'hours of exceedance' is relatively easier to pass (in Case $2 \&$ 3, only room F1.17 failed this criterion, even in Case 1, 5 rooms passed this criterion), seconded by the maximum temperature difference criterion (between maximum indoor operative temperature and the comfort upper limiting temperature). The most difficult criterion of the three is the daily weighted exceedance, all the rooms failed by a relatively big margin, even in Case 3 where the other two criteria either passed or close to pass, but for $W_{e}$ the smallest is 11 which is nearly double the requirement of 6 .

Table 3 Thermal comfort compliance data for various conditions against BB101 2018 requirement

\begin{tabular}{|c|c|c|c|c|c|c|c|c|c|c|c|}
\hline Cases | & Criteria & G.02 & G.20 & G.22 & F1.17 & F1.18 & F1.19 & F1.20 & S2.07 & S2.09 & T3.09 \\
\hline \multirow{4}{*}{ As built } & $\begin{array}{l}\text { Hours of } \\
\text { Exceedance } \leq 40\end{array}$ & 41 & 149 & 114 & 154 & 84 & 44 & 38 & 60 & 78 & 50 \\
\hline & $\begin{array}{l}\text { Daily weighted } \\
\text { exceedance } \leq 6\end{array}$ & 22 & 35 & 32 & 38 & 32 & 25 & 20 & 25 & 27 & 23 \\
\hline & $\begin{array}{l}\text { The temperature } \\
\text { difference } \leq 4 \mathrm{~K}\end{array}$ & 5 & 8 & 8 & 8 & 7 & 6 & 5 & 6 & 6 & 5 \\
\hline & Pass (Yes/No) & No & No & No & No & No & No & No & No & No & No \\
\hline \multirow{4}{*}{ Case 1} & $\begin{array}{l}\text { Hours of } \\
\text { Exceedance } \leq 40\end{array}$ & 33 & 115 & 80 & 107 & 52 & 40 & 35 & 37 & 47 & 33 \\
\hline & $\begin{array}{l}\text { Daily weighted } \\
\text { exceedance } \leq 6\end{array}$ & 19 & 33 & 28 & 32 & 26 & 23 & 19 & 20 & 23 & 19 \\
\hline & $\begin{array}{l}\text { The temperature } \\
\text { difference } \leq 4 \mathrm{~K}\end{array}$ & 5 & 8 & 7 & 7 & 7 & 6 & 5 & 5 & 5 & 5 \\
\hline & Pass $(\mathrm{Yes} / \mathrm{No})$ & No & No & No & No & No & No & No & No & No & No \\
\hline \multirow{4}{*}{ Case 2} & $\begin{array}{l}\text { Hours of } \\
\text { Exceedance } \leq 40\end{array}$ & 14 & 28 & 39 & 50 & 30 & 25 & 17 & 15 & 24 & 13 \\
\hline & $\begin{array}{l}\text { Daily weighted } \\
\text { exceedance } \leq 6\end{array}$ & 13 & 19 & 21 & 24 & 18 & 17 & 13 & 13 & 14 & 12 \\
\hline & $\begin{array}{l}\text { The temperature } \\
\text { difference } \leq 4 \mathrm{~K}\end{array}$ & 4 & 5 & 6 & 6 & 5 & 5 & 4 & 4 & 4 & 4 \\
\hline & Pass (Yes/No) & Yes & No & No & No & No & No & Yes & Yes & Yes & Yes \\
\hline \multirow{4}{*}{ Case 3} & $\begin{array}{l}\text { Hours of } \\
\text { Exceedance } \leq 40\end{array}$ & 14 & 23 & 37 & 44 & 30 & 21 & 15 & 15 & 15 & 12 \\
\hline & $\begin{array}{l}\text { Daily weighted } \\
\text { exceedance } \leq 6\end{array}$ & 13 & 18 & 20 & 22 & 18 & 14 & 13 & 13 & 13 & 11 \\
\hline & $\begin{array}{l}\text { The temperature } \\
\text { difference } \leq 4 \mathrm{~K}\end{array}$ & 4 & 5 & 6 & 6 & 5 & 5 & 4 & 4 & 4 & 3 \\
\hline & Pass (Yes/No) & Yes & No & No & No & No & No & Yes & Yes & Yes & Yes \\
\hline
\end{tabular}

Figure 2 illustrates the warmest day on the $22^{\text {nd }}$ of July from the weather data (London Heathrow pDSY-1 2020). Weather parameters and simulated room variables for Case 3 are plotted to show how the overheating severity criteria are assessed. The dashed line is the comfort upper limiting temperature on the day, the temperature difference $\Delta T_{\max }\left(\Delta T_{\max }=T_{o p-\max }-T_{c . u . l . t}\right)$ is rounded to $6 \mathrm{~K}$, which fails 
to meet the target difference $(4 \mathrm{~K})$. $T_{\text {c.u.l.t }}$ (calculated from equations 2 to 4 ) is directly associated with the running mean temperature $T_{r m}$ and this running mean temperature is derived from the outdoor daily mean temperature based on the adaptive approach. $\Delta T_{\max }$ is relatively easier to meet $(5$ spaces passed in Case 3 ) than the daily accumulated number of hours over $\left(W_{e}\right)$ criterion (none of the assessed spaces passed in Case 3). This is due to the nature how $W_{e}$ is calculated (the sum of all $\Delta T$ the rounded during the occupancy time, for this case it is 22 ).

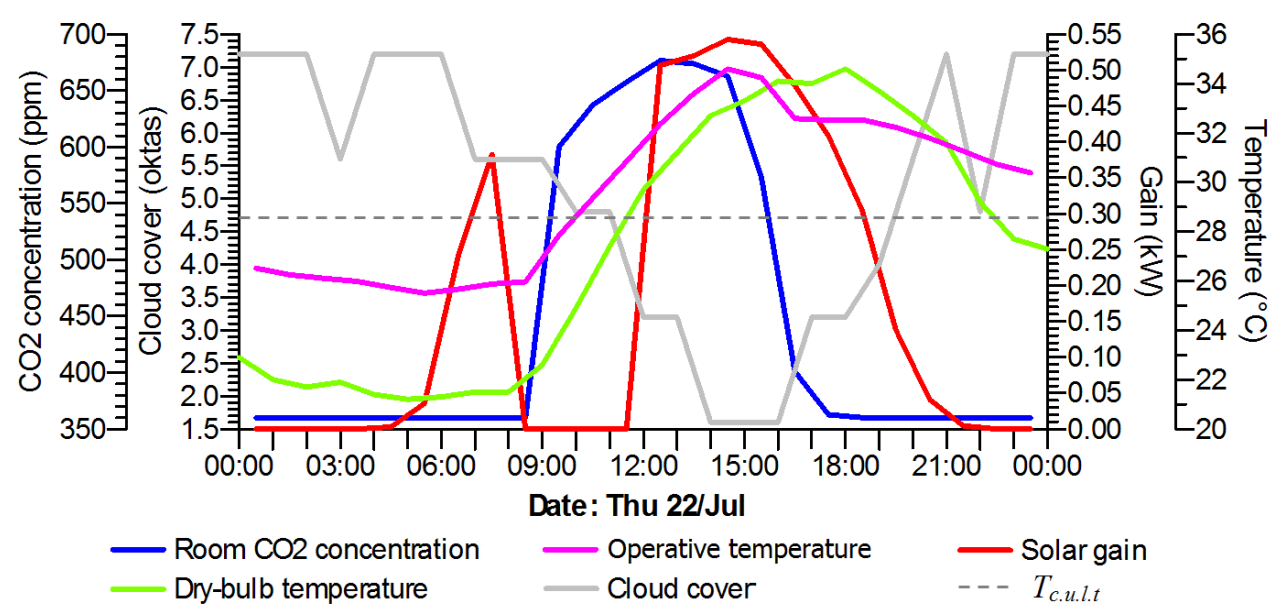

Fig. 2 Peak day parameters for room F1.17 from Case 3 (operative temperature, outdoor dry-bulb temperature, comfort upper limiting temperature, solar gain, cloud cover \& room $\mathrm{CO}_{2}$ concentration)

The simulation outputs for $\mathrm{CO}_{2}$ concentration in each space is shown in Table 4. The maximum $\mathrm{CO}_{2}$ concentrations are all lower than the required target 2000ppm, while for the Average (maximum daily average) $\mathrm{CO}_{2}$ requirement it is a different story: many spaces failed to pass this criterion for the cases considered. The used control logic for window opening on $\mathrm{CO}_{2}$ concentration is from 'closed to fully open' when $\mathrm{CO}_{2}$ concentration is from $800 \mathrm{ppm}$ to $2000 \mathrm{ppm}$, which could be adjusted (i.e. from $800 \mathrm{ppm}$ to $1000 \mathrm{ppm}$ as suggested by [4]). Attempts were made but this control itself does not work as windows were also controlled by a threshold temperature (currently set as $20^{\circ} \mathrm{C}$ ). The venting windows would only open when the outdoor temperature reaches $20^{\circ} \mathrm{C}$, and this setting overwrites the ramp function settings for both $\mathrm{CO}_{2}$ concentrations and indoor temperatures (from $20^{\circ} \mathrm{C}$ to $24^{\circ} \mathrm{C}$ ). As shown in Figure 3, the higher $\mathrm{CO}_{2}$ concentrations always happened in days where outdoor temperature are lower. For warmer days, the venting windows would have been partially or fully opened so adequate amount of ventilation would have been achieved, so lowered $\mathrm{CO}_{2}$ concentrations (i.e. second half of June, July and August). Due to the temperature difference between indoor and outdoor in colder days, windows can always be opened to boost ventilation and subsequently lowering down the $\mathrm{CO}_{2}$ concentrations. This can be achieved by setting a lower threshold window opening temperature, or, in practice, open venting windows manually to achieve this. The considered natural ventilation strategy in this work can provide adequate ventilation for regulating $\mathrm{CO}_{2}$, however, in practice, one has to consider the potential cold draft in colder days during the assessment time period. Generally speaking, from the assessments conducted in this research, overheating is far more difficult to tackle than the $\mathrm{CO}_{2}$ associated indoor air quality.

Table $4 \mathrm{CO}_{2}$ concentrations of each modelled space under different simulation scenarios

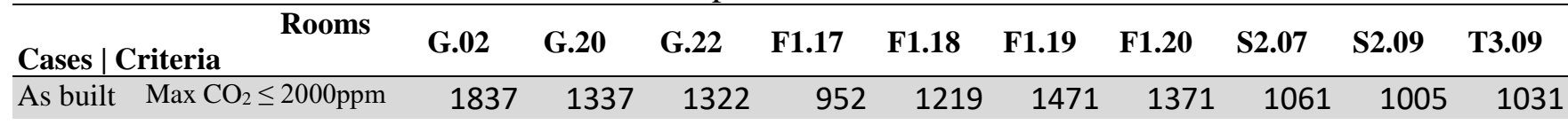




\begin{tabular}{llrrrrrrrrrr} 
& Average $\leq 1000 \mathrm{ppm}$ & 1096 & 1116 & 1069 & 724 & 859 & 995 & 1047 & 905 & 852 & 866 \\
Case 1 & Max $\mathrm{CO}_{2} \leq 2000 \mathrm{ppm}$ & 1427 & 1199 & 1147 & 1129 & 1383 & 1364 & 1276 & 1578 & 1561 & 1568 \\
& Average $\leq 1000 \mathrm{ppm}$ & 1059 & 941 & 945 & 766 & 941 & 992 & 1010 & 1088 & 1033 & 1008 \\
Case 2 & Max $\mathrm{CO}_{2} \leq 2000 \mathrm{ppm}$ & 1889 & 1204 & 1160 & 1190 & 1410 & 1482 & 1408 & 1725 & 1637 & 1741 \\
& Average $\leq 1000 \mathrm{ppm}$ & 1136 & 945 & 950 & 830 & 1009 & 1027 & 1043 & 1174 & 1126 & 1177 \\
Case 3 & Max $\mathrm{CO}_{2} \leq 2000 \mathrm{ppm}$ & 1889 & 1209 & 1160 & 1483 & 1446 & 1482 & 1408 & 1722 & 1637 & 1741 \\
& Average $\leq 1000 \mathrm{ppm}$ & 1121 & 954 & 958 & 901 & 1036 & 1028 & 1046 & 1175 & 1127 & 1177 \\
\hline
\end{tabular}

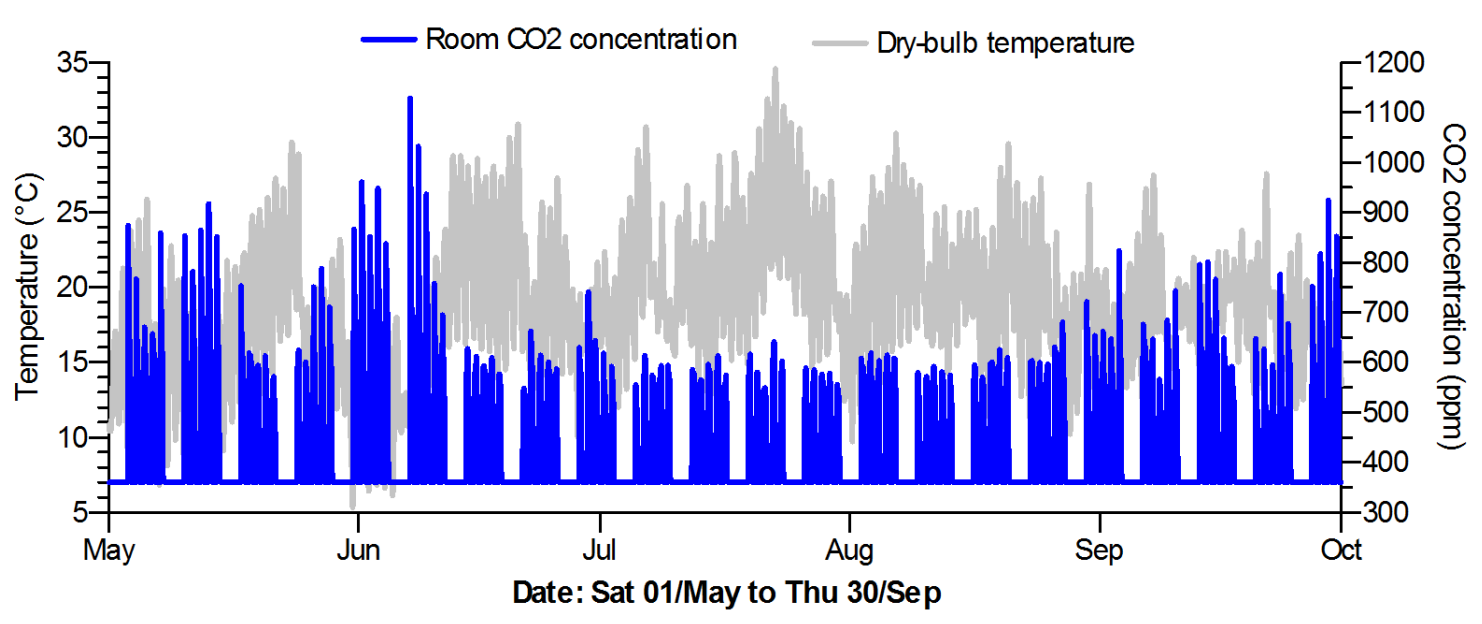

Fig. $3 \mathrm{CO}_{2}$ concentrations and outdoor dry-bulb temperature over simulation period for room F1.17

\section{Conclusions and discussions}

This paper presents a compliance calculation of an existing school building design using dynamic thermal simulation tool - IESVE. The requirements on the adaptive thermal comfort and $\mathrm{CO}_{2}$ based indoor air quality from the newly published BB101 2018 are the focus of the assessment. Ten teaching and learning spaces with various ventilation routes/areas were modelled with different case scenarios. The simulation results show that all the teaching and learning spaces will not pass the overheating criteria from the new BB101 under 'as built' conditions. With the changes made to the design in terms of promoting ventilation, providing solar shading as well as night purging, some of the spaces are able to pass the new compliance requirements in terms of thermal comfort. For $\mathrm{CO}_{2}$ concentration requirements, the design of the learning and teaching spaces provides adequate capacity in achieving lower $\mathrm{CO}_{2}$ concentrations although for some of the spaces the simulated results show otherwise. That was due to the control settings in colder days when venting windows were closed under the threshold temperature. In practice this can be easily adjusted. The research also highlighted that the overheating severity criterion - 'daily weighted exceedance', is much more difficult to pass than the other two criteria. This does raise the question whether this criterion was set appropriately. Due to the restriction of the existing design, alternative options were limited to what has been tested in this work. A systematic evaluation on the new BB101's adaptive thermal comfort criteria would be useful. The evaluation could include but not limited to: orientation, various types of shading, different ventilation strategies, appropriate night purging, materials of construction, etc., which will be subject to the future work. 


\section{ORCID Id of authors}

Ji, Yingchun: https://orcid.org/0000-0003-3003-5071

Du, Jiangtao: https://orcid.org/0000-0002-4307-4398

\section{References}

[1] Coley D, Greeves R \& Saxby B, 2007. The effect of low ventilation rates on the cognitive function of a primary school class. International Journal of Ventilation, vol 6, iss 2, pp $107-112$.

[2] Bako-Biro Z, Clements-Croome DJ, Kochhar N, Awbi HB \& Williams MJ, 2012. Ventilation rates in schools and pupils' performance. Building and Environment, vol 48, pp. 215-223.

[3] Barrett P, Davies F, Zhang Y \& Barrett L, 2015. The impact of classroom design on pupils' learning: Final results of a holistic, multi-level analysis. Building and Environment, Vol 89, pp. 118-133

[4] BB101 2018. Guidelines on ventilation, thermal comfort and indoor air quality in schools. Ver. 1, Aug 2018, Education \& Skill Funding Agency, https://www.gov.uk/government/publications [Accessed September 2018]

[5] BB101 2006. Ventilation of School buildings, 2006, ISBN 011-2711642. s.1.:s.n.

[6] CIBSE TM49 2014. Design Summer Years for London. London: The Charted Institution of Building Services Engineers. ISBN 978-1-906846-27-5

[7] CIBSE Guide J 2002. Weather, solar and illuminance data. London: The Charted Institution of Building Services and Engineers. ISBN 190328712 X

[8] Eames, M. 2016. An update of the UK's design summer years: Probabilistic design summer years for enhanced overheating risk analysis in building design. Building Serv. Eng. Res. Technol., vol 37, iss 5, pp. 503-522.

[9] Ji Y, Korolija I \& Zhang Y, 2017. Thermal responses of single zone offices on existing near-extreme summer weather data. Building Simulation, vol 1,1 iss 1, pp. 15-35.

[10] BS EN 15251 2007. Indoor environmental input parameters for design and assessment of energy performance of buildings addressing indoor air quality, thermal environment, lighting and acoustics. 2007, s.1.: BSI, EN

[11] CIBSE Guide A 2015. Environmental design. London: Charted Institution of Building Services Engineers, ISBN 978-1-906846-55-8 (PDF).

[12] CIBSE TM52, 2013. The limits of thermal comfort: avoiding overheating in European buildings. London: The Charted Institution of Building Services Engineers. ISBN 978-1-906846-34-3.

[13] Ji Y, Swan W, Fitton R \& Fernando T, 2018.Assessing the requirements from 'BB101' 2006 and 2018for a naturally ventilated preparatory school in the UK. Building Serv. Eng. Res. Technol. DOI: $10.1177 / 0143624418815785$

[14] IESVE 2018. Integrated Environmental Solutions Virtual Environment. Available at: Www.iesve.com [Accessed October 2018]. 